\title{
Pengaruh Gelombang Elektromagnetik Terhadap Pertumbuhan Tanaman Oriza Sativa di Lingkungan Mikrografitasi
}

\author{
Arda Surya Editya ${ }^{1)}$, Istas Pratomo ${ }^{2)}$ \\ ${ }^{1,2)}$ Jurusan Teknik Elektro- Institut Teknologi Sepuluh Nopember \\ Jl. Raya ITS, Sukolilo, Kota SBY, Jawa Timur 60111 \\ Email : ardasurya@gmail.com
}

\begin{abstract}
ABSTRAK
Adanya teknologi nirkabel maka secara tidak langsung banyak pengaruh yang besar bagi kelangsungan makhluk hidup, mulai dari sisi negatifnya hingga dampak positifnya, seperti pengaruhnya elektromagnetik terhadap tumbuhan. Pada penelitian sebelumnya yang dilakukan oleh Racuciu, Lftode dan Miclaus mengemukakan bahwa terdapat pengaruh pertumbuhan pada tanaman jagung yang diberi pengaruh gelombang elektromagnetik dengan frekuensi $1 \mathrm{GHz}$. Pada paper kali ini akan dibahas tentang hasil eksperimen percobaan yang berusaha menggabungkan antara pengaruh gelombang elektromagnetik $2.4 \mathrm{GHz}$ dengan lingkungan mikrografitasi terhadap tanaman oriza sativa (padi). Hasil dari eksperimen dapat disimpulkan bahwa gelombang elektromagnetik 2.4 $\mathrm{GHz}$ memiliki pengaruh dalam tumbuh kembang tanaman oriza sativa (padi) pada lingkungan mikrografitasi.
\end{abstract}

\section{Kata-kata kunci: Elektromagnetik, Mikrogravitasi, tumbuhan.}

\section{PENDAHULUAN}

Dewasa ini perkembangan dunia komputer Tumbuhan adalah salah satu jenis makhluk hidup yang memiliki banyak manfaat terhadap kelangsungan hidup manusia. Indonesia adalah salah satu negara agraris dimana hampir sebagian besar penduduknya bercocok tanam, hal ini dikarenakan faktor alam Indonesia yang memiliki iklim tropis dan juga tekstur tanah yang sangat subur sehingga mendorong sebagian besar penduduknya bercocok tanam. Selain itu makanan pokok orang Indonesia adalah nasi yang notabenya berasal dari tanaman padi (oriza sativa).

Pada saat ini banyak penelitian-penelitian yang dilakukan untuk mengembangkan bibit padi yang unggul yang bertujuan untuk menghasilkan padi yang lebih banyak guna mencukupi kebutuhan pangan rakyat Indonesia, Seperti yang kita ketahui lahan yang digunakan untuk persawahan semakin kecil dikarenakan banyak pembangunan gedung dan perumahan terutama didaerah perkotaan.

Seiring dengan berkembangnya teknologi informasi banyak teknologi baru yang mempermudah kehidupan manusia, salah satunya yakni dengan teknologi komunikasi nirkabel. Dengan teknologi ini memungkinkan manusia berkomunikasi jarak jauh dengan memanfaatkan gelombang elektromagnetik sebagai media penghantarnya. Semakin maraknya teknologi ini digunakan dalam kehidupan sehari-hari maka berdampak pada banyaknya BTS (Base Terminal Station) atau yang sering kita sebut Tower. Tentu dengan semakin banyaknya Tower yang didirikan maka akan membawa dampak yang besar bagi makhluk hidup yang tinggal di sekitar Tower. Selama ini penelitian-penelitian yang meneliti tentang pengaruh radiasi gelombang elektromagnetik hanya berfokus pada manusia saja, sehingga para peneliti jarang ada yang meneliti dampak 
radiasi elektromagnetik bagi hewan dan tumbuhan.

Lingkungan luar angkasa dimana manusia jarang untuk memikirkan dampak dari lingkungan luar angkasa tersebut terhadap kehidupan makhluk hidup. Hal ini dikarenakan sulitnya untuk membangun sebuah kondisi yang sama seperti di luar angkasa. Pada saat ini kita dapat membangun sebuah kondisi dimana kondisi tersebut hampir menyerupai kondisi diluar angkasa dengan adanya alat bernama klinostat. Menurut Fathona dkk. [4] mengemukakan bahwa Klinostat dibangun dengan maksud menciptakan sebuah lingkungan dengan gravitasi mendekati nol. Dari fakta yang disajikan diatas maka peneliti tertarik untuk melakukan penelitian yang bertujuan untuk mencari hubungan antara perkembangan tumbuhan padi terhadap lingkungan luar angkasa dan radiasi gelombang elektromagnetik.

\section{DASAR TEORI}

Penelitian tentang pengaruh gelombang elektromagnetik pada pertumbuhan tanaman sebelumnya telah dilakukan oleh Racuciu, Lftode dan Miclaus [1] dengan gelombang elektromagnetik frekuensi $1 \mathrm{GHz}$ pada tanaman jagung dan menghasilkan data sebagai berikut jangka waktu paparan microwave yang berbeda dapat mempengaruhi perkecambahan biji dan perkembangan tanaman dimulai dengan proses seluler, seperti mitosis. Studi efek paparan microwave penting karena efek yang mengkhawatirkan mereka yang terjadi tidak hanya pada manusia tubuh atau hewan yang berbeda, tetapi juga pada organisme tumbuhan. Sebagai hasil dari studi eksperimental ini, kita dapat mengatakan bahwa rendah termal oven microwave $1 \mathrm{GHz}$ paparan mampu memulai efek mutagenik dan penghambatan proliferasi sel dan diferensiasi dalam biji terkena. Hal ini menandakan bahwa terdapat pengaruh gelombang elektromagnetik terhadap tumbuh kembang tanaman, lebih lanjut pada penelitian sebelumnya yang dilakukan oleh Igor Yu Petrov, Tatyana V. Moisseva dan Elvira V. Morozova tentang [5] pengaruh gelombang microwave terhadap tanaman hasilnya menunjukkan bahwa terdapat percepatan pertumbuhan dari biji sampai menjadi tanaman tanpa merubah struktur sel dari tanaman tersebut. Dari kedua peenelitian sebelumnya kita dapat mengetahui bahwa ada pengaruh gelombang elektromagnetik terhadap tanaman namun penelitian untuk meneliti lebih lanjut tentang pengaruh gelombang elektromagnetik terhadap tumbuhan ini. Pada paper kali ini peneliti mencoba untuk menerapkan pegaruh gelombang elektromagnetik terhadap tanaman pada lingkungan mikrogravitasi/ lingkungan luar angkasa. $A$. Klinostat

Seperti yang dikutip pada buku besutan United Nations Programme on Space Application klinostat dapat didefinisikan [2] berbagai macam clinostats telah dikembangkan, berbeda dalam jumlah sumbu rotasi dan mode operasi sehubungan dengan kecepatan dan arah rotasi. Bentuk klinostat ada yang berbentuk dua dimensi (2-D), atau satu sumbu, klinostat memiliki sumbu rotasi tunggal, yang berjalan tegak lurus dengan arah vektor gravitasi. Sebuah klinostat tiga dimensi (3-D) memiliki dua sumbu rotasi, yang tegak lurus satu sama lain. Klinostat jenis ini berjalan pada kecepatan konstan dan dalam arah yang konstan, secara khusus disebut klinostat 3D. Namun, jika kedua sumbu berputar pada kecepatan yang berbeda dan dalam arah yang berbeda. Studi saat ini berkonsentrasi pada perbandingan antara perangkat yang berbeda dalam rangka untuk menentukan kondisi simulasi yang tepat untuk objek yang diberi perlakuan. Klinostat dapat dilengkapi dengan kapasitas untuk mikroskopi, secara online pengukuran kinetik atau fiksasi kimia sampel selama rotasi. Sebuah rotasi pada klinostat sering disebut "clinorotation".

Lebih lanjut [2] analisis pergerakan klinostat didasarkan pada mekanika klasik mengenai rotasi dan kerangka non-inersia. Rotasi dari klinostat menimbulkan gaya fiktif karena terdapat kerangka koordinat sistem yang diputar dan kerangka koordinat yang diam. Kedua kerangka klinostat diputar dengan kelajuan sudut yang sama dengan sumbu putar,yang digambarkan sebagai garis putus-putus seperti ditunjukkan pada Gambar 1. 


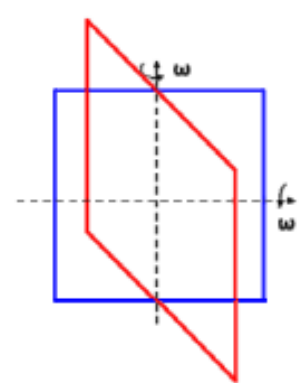

Gambar 1. Klinostat 3D yang dibangun dengan dua rangka

Pada suatu kerangka koordinat sistem yang diputar maka berlaku persamaan

$$
F^{\prime}=F-F_{C e n t}-F_{C o r}-F^{\prime \prime}
$$

Dengan $\mathrm{F}$ merupakan gaya relatif terhadap kerangka acuan yang diam, F' gaya relatif terhadap kerangka acuan berputar yaitu dua buah rangka klinostat, Fcent merupakan gaya sentrifugal, F" gaya yang diakibatkan oleh perubahan kecepatan putar terhadap waktu dan Fcor adalah gaya Coriolis yang ditimbulkan ketika partikel bergerak pada kerangka yang diputar. Sehingga dengan demikian terbentuklah lingkungan mikrografitasi.

\section{B. Tanaman Oriza Sativa (Padi)}

Tanaman padi ini merupakan tanaman yang dijadikan makanan pokok khususnya bagi warga Indonesia. Bahkan Tanaman hampir diseluruh wilayah Indonesia terdapat sawah yang menggambarkan bahwa pentingnya padi ini bagi masyarakat Indonesia.

Dewasa ini banyak perkembang biakan padi sehingga varietas padi semakin banyak macamnya. Pada umumnya padi mulai berkembang sekitar 5-6 bulan. [4] Pertumbuhan tanaman padi dibagi ke dalam tiga fase: (1) vegetatif (awal pertumbuhan sampai pembentukan bakal malai/primordia); reproduktif (primordia sampai pembungaan); dan (3) pematangan (pembungaan sampai gabah matang).

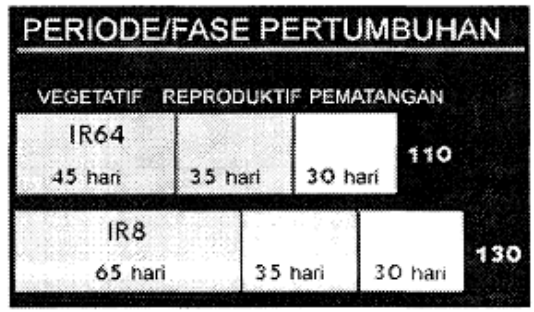

Gambar 2. Gambar periode berdasar jenis padi

\section{Efek Gravitasi Terhadap Tumbuhan}

Efek gravitasi ternyata sangat berpengaruh pada pertumbuhan tanaman seperti dikutip pada buku besutan United Nations Programme on Space Application mengemukakan bahwa [3] grafitasi adalah stimulus yang menggunakan tanaman untuk tumbuh akarnya ke arah vektor gravitasi (bawah), penahan tanaman di tanah, dan untuk menumbuhkan tunas dalam arah yang berlawanan dari vektor gravitasi (atas), keluar dari tanah ke arah matahari. Untuk memahami "up" dan "down" adalah wajib untuk kelangsungan hidup tanaman di bumi.

Hal ini juga sangat diperlukan untuk semua kehidupan di bumi karena fotosintesis diperlukan untuk produksi makanan dan oksigen.

\section{HASIL DAN DISKUSI}

Dalam proses perancangan eksperimen ini kita akan menggunakan 3 subjek penelitian dan frekuensi gelombang elektromagnetik $2.4 \mathrm{GHz}$ untuk membuktikan bahwa terdapat pengaruh gelombang elektromagnetik frekuensi $2.4 \mathrm{GHz}$ terhadap pertumbuhan tanaman di lingkungan mkrogravitasi. Ketiga subjek tersebut dapat dijabarakan sebagai berikut :

1. Subjek $A=$ Tanaman padi yang diberi perlakuan gelombang elektromagnetik dan juga lingkungan mikrogravitasi.

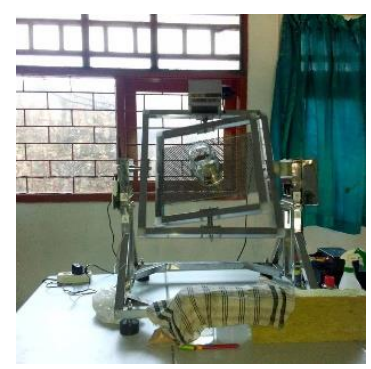

Gambar 3. Subjek A

2. Subjek $B=$ Tanaman padi yang hanya ditaruh di lingkungan mikrogravitasi.

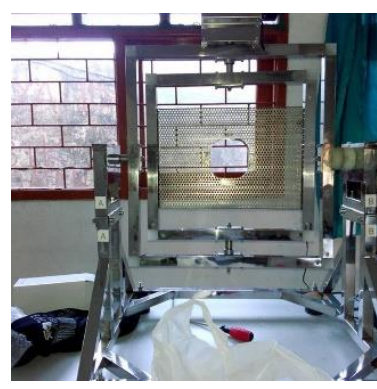

Gambar 4. Subjek B.

3. Subjek $\mathrm{C}=$ Tanaman Padi yang ditanam tanpa menggunakan radiasi elektromagnetik dan juga lingkungan mikrogravitasi. 


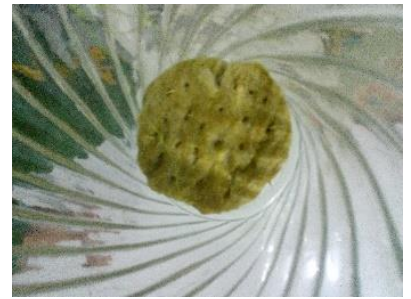

Gambar 5. Subjek C

Dari ketiga subjek yang diteliti tersebut maka dapat diperoleh hasil sebagai berikut :

Tabel 1. Hasil Eksperimen

\begin{tabular}{|c|c|c|}
\hline Subjek A & Subjek B & Subjek C \\
\hline $\begin{array}{l}\text { 1. Pertumbuh } \\
\text { an lebih } \\
\text { cepat. }\end{array}$ & $\begin{array}{l}\text { 1. Pertumbu } \\
\text { han } \\
\text { cenderung } \\
\text { lambat. }\end{array}$ & $\begin{array}{l}\text { 1. Pertumbuh } \\
\text { an normal. }\end{array}$ \\
\hline $\begin{array}{l}\text { 2. Gaya } \\
\text { pertumbuh } \\
\text { annya } \\
\text { kemotropis } \\
\text { me (akar } \\
\text { bergerak } \\
\text { ke arah } \\
\text { zat nutrisi) }\end{array}$ & $\begin{array}{l}\text { 2. Gaya } \\
\text { pertumbuh } \\
\text { annya } \\
\text { kemotropi } \\
\text { sme (akar } \\
\text { bergerak } \\
\text { ke arah } \\
\text { zat nutrisi) }\end{array}$ & $\begin{array}{l}\text { 2. Gaya } \\
\text { pertumbuh } \\
\text { annya } \\
\text { geotropis } \\
\text { me (akar } \\
\text { bergerak } \\
\text { ke bawah } \\
\text { karena } \\
\text { tertarik } \\
\text { oleh } \\
\text { gravitasi) }\end{array}$ \\
\hline $\begin{array}{l}\text { 3. Hasil } \\
\text { Mikroskopi } \\
\text { k Sel Akar }\end{array}$ & $\begin{array}{l}\text { 3. Hasil } \\
\text { Mikroskopi } \\
\text { k Sel Akar }\end{array}$ & $\begin{array}{l}\text { 3. Hasil } \\
\text { Mikroskopi } \\
\text { k Sel Akar }\end{array}$ \\
\hline $\begin{array}{l}\text { Gambar 6. Hasil } \\
\text { Sel akar } \\
\text { struktur sel } \\
\text { akar } \\
\text { tampak } \\
\text { berbeda } \\
\text { dari } \\
\text { normal. }\end{array}$ & $\begin{array}{l}\text { Gambar 7. Hasil Sel } \\
\text { akar } \\
\text { Struktur sel } \\
\text { akar tampak } \\
\text { berbeda dan } \\
\text { cenderung } \\
\text { lebih kecil. }\end{array}$ & $\begin{array}{l}\text { Gambar 8. Hasil } \\
\text { Sel akar } \\
\text { Struktur } \\
\text { sel akar } \\
\text { normal. }\end{array}$ \\
\hline
\end{tabular}

\section{KESIMPULAN}

Dari landasan teori dan juga hasil eksperimen yang telah dilakukan maka dapat diperoleh hasi sebagai berikut.

1. Dengan adanya radiasi elektromagnetik frekuensi $2.4 \mathrm{GHz}$ dapat mempercepat pertumbuhan hal ini dikarenakan radiasi gelombang elektromagnetik memanaskan sel tumbuhan sehingga fotosintesis dapat optimal.

2. Dengan adanya radiasi elektromagnetik frekuensi $2.4 \mathrm{GHz}$ dapat membantu tanaman untuk hidup di lingkungan mikrografitasi (luar angkasa) sehingga memungkinkan untuk adanya kehidupan di luar angkasa.

\section{Daftar pustaka}

[1]. R. Mihaela, I. Cora and M. Simona, " $1 \mathrm{GHz}$ Low-thermal Microwaves Effect on Miotic Division of Vegetal Tissues," International Conference and Exposition on Electrical and Power Engineering (EPE 2014), October 2014.

[2]. Fathona LW, Surrachman A, dkk, "Klinostat Tiga Dimensi sebagai Simulator Mikrogravitasi untuk Berbagai Eksperimen Tanpa Bobot," ITB Journal ISSN : 2085-2517, February 2011.

[3]. H. L. Krauss, C. W. Bostian, and F. H. Raab, Teacher's Guide to Plant Experiments in Microgravity, New York: United Nations, 2013.

[4]. Makarim Karim dan Suhartatik E.. Morfologi dan Fisiologi Tanaman Padi. November, 2009.

[5]. Petrov Igor Yu, Moiseeva Tatyana V. and Morozova Elvira V., "A Possibility of Correction of Vital Proccess in Plant Cell With Microwave Radiation", International Conference and Exposition on Electrical and Power Engineering.August, 1991 